\title{
The European Union's contribution to shaping the law on standing and jurisdiction in the context of international dispute settlement
}

\author{
Danae Azaria*
}

\section{Introduction}

The European Union ('EU') is an international organization ('IO') and, as such, a subject of international law. It participates in the formation of international law; it bears international obligations and holds rights; it engages international responsibility, if it commits an internationally wrongful act pertaining to a breach of its international obligations; and can invoke the responsibility of other subjects of international law. The invocation of international responsibility is the most usual subject matter of international disputes and thus a central issue in the context of international dispute settlement.

However, the machinery for invoking the international responsibility of IOs (or for implementing the responsibility of states by IOs) through judicial means of dispute settlement is limited in international law. The International Court of Justice ('ICJ') can only entertain contentious claims between states. ${ }^{1}$ Individuals can initiate proceedings only against states (rather than IOs) in arbitration proceedings under the International Centre for Settlement of Investment Disputes ('ICSID'). ${ }^{2}$

This paper argues that the practice of the EU (undoubtedly owing to its competences) has contributed to the development of international law in relation to international dispute settlement. First, the EU practice has contributed to the development of standing by and against IOs to bring a claim for a breach of international obligations within judicial dispute settlement fora, as well as outside such fora by resorting to countermeasures under law of international responsibility. Second, the EU has promoted an increasing treaty practice pursuant to which some international judicial fora enjoy jurisdiction over disputes between states and an IO, such as those under the Agreement Establishing the World Trade Organization ('WTO Agreement'), the United Nations Law of the Sea Convention ('LOSC'), and the Energy Charter Treaty ('ECT'). ${ }^{5}$ The following analysis begins with standing and then discusses jurisdiction.

\section{Standing in Customary International Law}

In international law, standing is the cause of action upon which a claim is based. It arises from '(a) the existence of an international obligation owed to another subject of international law or a group of subjects of international law; and (b) the conduct which

\footnotetext{
* Danae Azaria (PhD UCL, LLM UCL), Lecturer in Law, University College London (UCL): d.azaria@ucl.ac.uk.

1 Statute of the International Court of Justice, 39 AJIL Supp. (1945) 215.

${ }^{2}$ Convention on the Settlement of Investment Disputes Between States and Nationals of Other States (done 18 March 1965, entered into force 14 October 1966) 575 UNTS 159

${ }_{3}^{3}$ Marrakesh Agreement establishing the World Trade Organization (with final act, annexes, and protocol) (concluded 15 April 1994, entered into force 1 January 1995) 1867 UNTS 3.

${ }^{4}$ United Nations Convention on the Law of the Sea (done 10 December 1982, entered into force 16 November 1994) 1833 UNTS 3.

5 The Energy Charter Treaty (with annexes) (done 17 December 1994, entered into force 16 April 1998) 2080 UNTS 95, as amended by the Final Act of the International Conference and Decision by the Energy Charter Conference in respect of the Amendment to the Trade-Related Provisions of the Energy Charter Treaty, Annex 1 (adopted 24 April 1998, entered into force 21 January 2010) in The Energy Charter Treaty and Related Documents, 2004.
} 
has allegedly breached that obligation. ${ }^{6}$ In international courts and tribunals, standing is a matter of admissibility. It arises as an objection against the claim brought by the claimant and challenges whether the claimant has a legal interest to bring the claim. By contrast, despite the fact that a claimant may have standing to make a claim, the judicial/quasijudicial body may lack jurisdiction. ${ }^{7}$

Under the Articles on the Responsibility of States for Internationally Wrongful Acts ('ASR'), ${ }^{8}$ which reflect the state of customary international law on this point, and whose approach has also mutatis mutandis been transposed in the Articles on the Responsibility of International Organizations for Internationally Wrongful Acts ('ARIO'), ' injured states/international organisations may claim cessation, assurances and guarantees of nonrepetition of the internationally wrongful act, and reparation (ASR Article 42; ARIO 43). In contrast, states/international organisations other than an injured state/international organisation may claim cessation and assurances of non-repetition of the wrongful act, (ASR Article 48; ARIO 49(4)(b)). ${ }^{10}$

The distinction between injured subjects and subjects other than the injured subject is predicated on the classification of primary international obligations, as bilateral/bilateralisable, interdependent and erga omnes (partes). ${ }^{11}$ The latter two types are collectively owed obligations that are very different. Erga omnes obligations are owed invisibly and collectively among all international subjects, while erga omnes partes obligations are owed indivisibly and collectively among a group of subjects. ${ }^{12}$ These obligations transcend reciprocity, and set standards. By contrast, interdependent

${ }^{6}$ J. Crawford and A. Pellet, in I. Buffard, J. Crawford, A. Pellet, and S. Wittich (eds.), International Law between Universalism and Fragmentation (2008) 831-867. Cf. Pellet adds a third element: that the dispute is susceptible to judicial proceedings. Ibid. 848. However, this is not established in case law or literature. See also I. Brownlie, Causes of Action in the Law of Nations, 50 BYIL (1979) 13-41.

${ }^{7}$ On distinction between jurisdiction and admissibility: Hochtief $A G v$. the Argentine Republic, ICSID Case no $\mathrm{ARB} / 07 / 31$, Decision on Jurisdiction, 24 October https://icsid.worldbank.org/ICSID/FrontServlet?requestType=CasesRH\&actionVal=showDoc\&docId= DC2351_En\&caseId=C260, paras. 90-96; Giovanni Alemanni et al v. the Argentine Republic, ICSID Case no ARB/07/8, Decision on Jurisdiction and Admissibility, 17 November 2014, http://italaw.com/sites/default/files/case-documents/italaw4061.pdf, paras. 257-260.

${ }_{8}$ Text of the draft articles on the responsibility of states for internationally wrongful acts, Report of the Commission to the General Assembly on the work of its fifty-third session, Yearbook of the International Law Commission, 2001, Vol. II, pp. 26-30.

${ }_{9}$ Text of the draft articles on the responsibility of international organizations, Report of the International Law Commission, Sixty-third session (26 April-3 June and 4 July-12 August 2011), General Assembly, Official Records, Sixty-sixth session, Supplement No. 10 (A/66/10), pp. 52-66.

${ }_{10}$ According to the ASR/ARIO, they may also claim reparation in the interest of the injured state or of the beneficiaries of the obligation breached. However, this does not reflect lex lata but is a progressive development of the law. Text of the draft articles on responsibility of States for internationally wrongful acts with commentaries thereto, Report of the Commission to the General Assembly on the work of its fifty-third session, Yearbook of the International Law Commission, 2001, Vol. II, pp. 31-143 at 127, para. 12. The Commentary to the ARIO does not explicitly clarify that Article 49(4)(b) is a progressive development, as did the Commentary to ASR. Text of the draft articles with commentaries thereto, Report of the International Law Commission, Sixty-third session (26 April-3 June and 4 July-12 August 2011), General Assembly, Official Records, Sixty-sixth session, Supplement No. 10 (A/66/10), pp. 67-170, at 7781. However, the Commentary cross-refers to the ASR, which may allow the argument that this provision has been included as a progressive development of the law. Ibid, p. 78, para. 1.

${ }^{11}$ For explanation of the types of international obligations: L.-A. Sicilianos, The Classification of Obligations and the Multilateral Dimension of the Relations of International Responsibility, 13 EJIL (2002) 1127-1145.

12 Mainly created by treaty and binding on treaty parties. For instance, Questions relating to the Obligation to Prosecute or Extradite (Belgium v. Senegal), Judgment, ICJ Reports 2012, p. 422, para. 66; Whaling in the Antarctic (Australia v. Japan: New Zealand intervening), Merits, Judgment of 31 March 2014: http://www.icjcij.org/docket/files/148/18136.pdf. 
obligations are indivisibly and collectively owed but are fundamentally characterised by global reciprocity. All parties have to perform for any of them to perform. ${ }^{13}$

For the purpose of the ASR and ARIO, invocation of international responsibility involves claims of 'relative formality', such as recourse to a method of dispute settlement or unilateral countermeasures against the responsible subject. Mere protests are not a means of invoking international responsibility. ${ }^{14}$

Given that countermeasures are the default means of invoking responsibility in the absence of special mandatory means for settling the dispute between the parties, the following sections examine first countermeasures. Judicial (and quasi-judicial) means of dispute resolution are discussed separately as it is in that context that jurisdictional restrictions also appear. It will be shown that the practice of the EU has been important in relation to influencing the development of the law in relation to both these issues.

\subsection{Countermeasures as a Means of Invoking International Responsibility}

Having explained the rules of standing under general customary international law, this section discusses the relationship between countermeasures and international dispute settlement. Countermeasures are inextricably connected to dispute settlement for a number of reasons. Most disputes that end up in judicial (or quasi-judicial) fora involve questions of responsibility. Countermeasures may prompt the responsible state to get involved in the settlement of the dispute (or comply with its obligation to participate in dispute settlement where such obligation exist); indeed this is the very purpose of countermeasures. Additionally, countermeasures may have the unintended effect of aggravating international disputes, and involve a significant risk: they are premised on auto-determination, which can lead to wrongful conduct by the subject resorting to them.

The following sections thus first explain the function of countermeasures in international law. Resorting to countermeasures presupposes standing to invoke international responsibility. Second they expound on whether countermeasures can be taken instead of or in parallel with international dispute settlement procedures, and on whether countermeasures are a means that aggravates a dispute compromising its resolution or a means of expediting the resolution of an international dispute. This is especially so, given that countermeasures taken by the EU are operationalized by EU member states against the responsible third state, and as such they may have significant consequences on the third state.

\subsubsection{The Function of Countermeasures}

Countermeasures represent a means of self-help aimed at providing the means to the injured subject to satisfy its claim in the context of a decentralized system of enforcement. Under the law of international responsibility countermeasures have a double function. First, they are a means of implementing international responsibility. They are unilateral measures taken against the responsible subject in response to a prior

\footnotetext{
${ }^{13}$ Special Rapporteur Fitzmaurice, Second Report on the Law of Treaties, A/CN.4/107, Yearbook of the International Law Commission, 1957, Vol. II, p. 53, para. 120, p. 54, para. 126; Special Rapporteur Fitzmaurice, Third Report on the Law of Treaties, A/CN.4/115, Yearbook of the International Law Commission, 1958, Vol. II, p. 44, para. 91. D. Azaria, Treaties on Transit of Energy via Pipelines and Countermeasures (Oxford University Press, 2015), p. 109.

${ }^{14}$ Text of the draft articles on responsibility of States for internationally wrongful acts with commentaries thereto, Report of the Commission to the General Assembly on the work of its fifty-third session, Yearbook of the International Law Commission, 2001, Vol. II, pp. 31-143 at 117, para. 2.
} 
breach of an international obligation owed to the subject taking the countermeasure. They are intended to induce the responsible subject to comply with its obligation to cease the internationally wrongful act and to make reparation. Second, at the same time, countermeasures are circumstances that preclude wrongfulness. Countermeasures are wrongful acts themselves, but the wrongfulness that they entail is precluded owing to the prior violation of international law to which they are responding.

Countermeasures are different from retorsion, ${ }^{15}$ and treaty responses to treaty breaches. ${ }^{16}$ They also differ from sanctions. 'While countermeasures are acts that would per se be unlawful, sanctions are lawful measures that an international organization may take against its members according to the rules of the organization'. ${ }^{17} \mathrm{By}$ contrast, responses (that pertain to the suspension of performance of international obligations) taken by an international organization against a responsible state that is not its member are countermeasures against a responsible state, not a sanction. ${ }^{18}$

\subsubsection{The Relationship between Countermeasures and International Dispute Settlement}

This paper discusses countermeasures given that they relate to international dispute settlement. In their adopted form the ASR include a number of provisions concerning the relationship between countermeasures and dispute settlement. First, the subject taking countermeasures is not relieved from fulfilling its obligation under any dispute settlement procedure applicable between it and the responsible state (ASR Article 50(2)). Second, before taking countermeasures the injured subject is obliged to call upon the responsible subject to fulfill its secondary obligations and to notify it of its decision to take countermeasures and offer to negotiate (ASR Article 52(1)). Third, 'countermeasures cannot be taken and if taken must be suspended without undue delay if the internationally wrongful act has ceased and the dispute is pending before a court or tribunal with the authority to make decisions binding on the parties', as long as the responsible subject implements the dispute settlement procedures in good faith (ASR Article 52(3)-(4)). Fourth, urgent countermeasures may be taken when necessary to preserve the rights of the injured subject, in which case the acting state does not need to notify and offer negotiations (ASR Article 52(2)). Fifth, lex specialis may exclude countermeasures as a means of invoking responsibility (ASR Article 55).

\footnotetext{
${ }^{15}$ Retorsion does not involve a breach of an international obligation but only an unfriendly act. P. Reuter, Droit International Public (Presse Universitaire de France, 1976), pp. 399-400; E. Zoller, Peacetime Unilateral Remedies (Transnational Publishers, 1984), pp. 5-9, 43-44.

${ }^{16}$ Countermeasures involve the suspension of performance of any obligation owed to the responsible state, and are aimed at inducing the latter to comply with its obligations, while treaty law responses can only be taken in the form of suspending the treaty's operation in response to a material breach of the same treaty and they purport to rebalance the treaty relationship that was de-stabilised by the material breach. Gabčvkovo-Nagymaros Project (Hungary/Slovakia), Judgment of 25 September 1997, ICJ Reports 1997, p. 7, para. 47; Separate Opinion of Judge Simma, Application of the Interim Accord of 13 September 1995 (the former Yugoslav Republic of Macedonia v. Greece), ICJ Reports 2011, p. 695 at 704, para. 20; B. Simma and C. Tams, Article 60, in O. Corten and P. Klein (eds), The Vienna Conventions on the Law of Treaties (Oxford University Press, 2011), pp. 1351-1378 at 1376-1377.

${ }^{17}$ Special Rapporteur Gaja, Seventh Report on Responsibility of International Organizations, 27 March 2009, A/CN.4/610, para. 111.

${ }^{18}$ L.-A. Sicilianos, in L. Picchio Forlati and L.-A. Sicilianos (eds.), Economic Sanctions in International Law (2004), p. 19. For other differences: Sicilianos, ibid, pp. 17-25; J. Crawford, The Relationship Between Sanctions and Countermeasures, in V. Gowlland-Debbas (ed.), United Nations Sanctions and International Law (Kluwer Law International, 2001), 57-68.
} 
While countermeasures may contribute to the willingness of the responsible subject to engage in peaceful settlement, ${ }^{19}$ it is preferable to resort to third-party determination than to unilateral means of enforcement. The latter are based on auto-determination as to whether an internationally wrongful act has occurred and inherently involve a risk of wrong determination on this point. As a result, owing to their unilateral nature and the auto-determination on which they are predicated, countermeasures are likely to aggravate the dispute. Nonetheless, the ASR (and arguably customary international law) do not include a rule that requires that there is recourse to third-party dispute settlement before resorting to countermeasures, and this matter remains open to debate (and subject to the determination of lex specialis). ${ }^{20}$

\subsubsection{The EU Practice}

\subsubsection{EU/Faroe Islands dispute}

The dispute between the EU and the Faroe Islands concerning the Total Allowable Catch ('TAC') for the Atlanto-Scandian herring stock illustrates the widespread practice of the EU in law-making with third states and other actors, and denotes the variety of disputes that the EU can be and has been involved in view of its competences. Importantly, the dispute illustrates the caution of the EU's conduct in determining its measures as responses under the law of international responsibility (i.e. countermeasures).

A particular element of this case is the peculiar status of the Faroe Islands under international law. The Faroe Islands are a self-governing territory within Denmark, but not a state. ${ }^{21}$ Whilst Denmark is a member to the EU, the founding treaties of the Union do not apply to the Faroe Islands by express provision in the Treaty for the Functioning of the European Union ('TFEU'). ${ }^{22}$ Although it cannot be argued that the Faroe Islands have a general capacity to conclude international agreements with subjects of international law, they have concluded such agreements. More specifically, in 2007, the Faroe Islands, Russia, Iceland, Norway and the EU agreed on an annual TAC for the

\footnotetext{
${ }^{19}$ Case concerning the Air Service Agreement of 27 March 1946 between the United States of America and France, RIAA, Vol. XVIII, pp. 417-493 (9 December 1978), paras. 94-95; K. Zemanek, The Unilateral Enforcement of International Obligations, 47 Zeitschrift für ausländisches öffentliches Recht und Völkerrecht (1987) 32-43 at 37.

${ }^{20}$ First, it has been argued that countermeasures are excluded when there are treaty means for the peaceful settlement of a dispute, and so countermeasures are available only if treaty means have been exhausted but have not effectively functioned. D.W. Bowett, Reprisals Involving Recourse to Armed Force, 66 AJIL (1972) 11; B. Simma, Counter-Measures and Dispute Settlement: A Plea for a Different Balance, 5 EJIL (1994) 102-105; ILC members who supported this position without taking a view on whether this is positive law: Economides, ILCYB 2001-I, p. 115, para. 7; Montaz, ibid., p. 116, para. 14. Second, it has been maintained that countermeasures are not ipso facto affected by the existence of clauses for the peaceful settlement of disputes, but there are instances where countermeasures are prohibited. Case concerning the Air Service Agreement of 27 March 1946 between the United States of America and France, RIAA, Vol. XVIII, pp. 417-493 (9 December 1978); For ILC members endorsing this position as being one of positive law: Rosenstock, ILC Yearbok 2001-I, p. 16, para. 51 and p. 54-55, para. 29; Tomka, ibid., p. 54, para. 24 and p. 117, para. 27; Rao, ibid., p. 57, para. 42.

${ }^{21}$ Albeit it could be argued that they are entities proximate to a state, for which Denmark exercises international relations. J. Crawford, The Creation of States in International Law (Oxford University Press, $2^{\text {nd }}$ ed, 2006), p. 739.

22 See, Treaty of Lisbon amending the Treaty on European Union and the Treaty establishing the European Community. OJ C 306, 2007/C 306/01. According to TFEU Article 355(5)(a) 'the Treaties shall not apply to the Faroe Islands'.
} 
Atlanto-Scandian herring stock. ${ }^{23}$ For the purpose of this agreement, the Faroe Islands are party to it. ${ }^{24}$

The 2007 Agreed Record of Conclusions of Fisheries Consultations on the Management of the Norwegian Spring-Spawning (Atlanto-Scandian) Herring Stock in the North-East Atlantic included an agreement on an annual Total Allowable Catch ('TAC') for the Atlanto-Scandian herring stock. ${ }^{25}$ The agreement also provided that in subsequent years the parties would restrict their fishing on the basis of a TAC consistent with a set fishing mortality rate as defined by the International Council for the Exploration of the Seas ('ICES'). Moreover, they would revise these management measures jointly on the basis of any advice by ICES. ${ }^{26}$

In 2013, when the Faroe Islands allegedly unilaterally decided to increase their TAC ${ }^{27}$ the European Commission on behalf of the EU unilaterally responded to what it considered a breach of the international agreement on the management of the stock by the Faroe Islands. ${ }^{28}$ The Commission 'notif[ied] the Home Government of the Faeroe Islands and the Government of Denmark its intention to identify the Faeroe Islands as a country allowing non-sustainable fishing, indicating the reasons for that identification and describing the possible measures that may be taken pursuant to [Regulation 1026/2012]. ${ }^{29}$ The measures that were to be taken under Regulation 1026/2012 consist in quantitative import restrictions of 'fish of any associated species, and fishery products made of or containing such fish, when caught while conducting fisheries on the stock of common interest under the control of [the country identified as a country allowing nonsustainable fishing]' (Article 4(d), Regulation 1026/2012). These measures were inconsistent with the obligations of the EU under the General Agreement on Tariffs and Trade ('GATT'), and more particularly Article IX. ${ }^{30}$

The question arises whether the measures were taken as a countermeasure against the allegedly responsible Faroe Islands for a breach of an international agreement to which the EU was party, or whether they were measures 'relating to the conservation of exhaustible natural resources [...] made effective in conjunction with restrictions on domestic production or consumption' that are both part of the general exceptions of the

\footnotetext{
${ }^{23}$ Agreed Record of Conclusions of Fisheries Consultations on the Management of the Norwegian SpringSpawning (Atlanto-Scandian) Herring Stock in the North-East Atlantic for 2007, 18 January 2007: http://www.fisk.fo/media/3618/190107_norðhavssildin_2007.pdf.

${ }^{24}$ Such international agreements are not treaties within the meaning of Article 2(1)(a) of Vienna Convention on the Law of Treaties (done 23 May 1969, entered into force 27 January 1980) 1155 UNTS 331, or the Vienna Convention on the Law of Treaties between States and International Organizations or between International Organizations (done 21 March 1986, not yet in force) Doc. A/CONF.129/15, reproduced in 25 ILM 543. There is no evidence in the 2007 Agreement itself or the subsequent conduct of the parties to it that the latter was not an agreement governed by international law. The subject-matter itself indicates that it is an agreement governed by international law.

${ }^{25}$ Agreed Record of Conclusions of Fisheries Consultations on the Management of the Norwegian SpringSpawning (Atlanto-Scandian) Herring Stock in the North-East Atlantic for 2007, 18 January 2007: http://www.fisk.fo/media/3618/190107_norðhavssildin_2007.pdf.

${ }_{26}$ Annex II, paras. 2 and 4, ibid. See also reference to these provisions of the agreement in Preamble para. 3, Commission Implementing Regulation (EU) No 793/2013 of 20 August 2013 establishing measures in respect of the Faeroe Islands to ensure the conservation of the Atlanto-Scandian herring stock.

${ }_{27}$ Preamble paras. 8-9, 13, Commission Implementing Regulation (EU) No 793/2013 of 20 August 2013 establishing measures in respect of the Faeroe Islands to ensure the conservation of the Atlanto-Scandian herring stock.

28 Ibid.

${ }^{29}$ Decision C(2013) 2853 of 17.5.2013.

${ }^{30}$ General Agreement on Tariffs and Trade, Annex IA to the Agreement establishing the World Trade Organization (done 15 April 1994, entered into force 1 January 1995) 1867 UNTS 3.
} 
GATT found in its Article XX(g). ${ }^{31}$ If the measures fell within the ambit of the general exceptions of GATT Article XX, the EU would not have violated its obligation under GATT Article IX. In such case, the examination of whether the measure was a lawful countermeasure under customary international law would be unnecessary, because countermeasures themselves constitute an unlawful act (whose wrongfulness is precluded). ${ }^{32}$

On the other hand, the measures may have been taken on the basis of multiple justifications. ${ }^{33}$ It may be argued that the rationale underlying the Union's responses to the perceived breach of the 2007 agreement by the Faroe Islands was to meet primarily the

31 The Panels and the AB have generally adopted two steps for the assessment of the lawful use of GATT Article XX by WTO members: first the specific exceptions in the sub-sections of the article have to be met; second, if the first step is satisfied, the requirements of the chapeau have to be met. Appellate Body Report, United States-Import Prohibition of Certain Shrimp and Shrimp Products, WT/DS58/AB/R, adopted 6 November 1998, paras. 118-119, and 147; Appellate Body Report, China-Measures Related to the Exportation of Various Raw Materials, WT/DS394/AB/R, WT/DS395/AB/R, WT/DS398/AB/R, adopted 22 February 2012 para. 354.

32 Further analysis on the relationship between treaty exceptions and circumstances precluding wrongfulness under customary international law in general and in relation to the WTO Agreement: Azaria, (2015), supra note 13 at 80-88.

33 Their purpose, content, as well as the manner and context in which they have been adopted are important in order to determine whether they are taken for the one or the other reason or even for both. First, the stated purpose of measures for the purpose of the conservation of fish stocks in relation to countries allowing non-sustainable fishing according to the Preamble of Regulation 1026/2012 is 'to encourage that country to contribute to the conservation of that stock'. Para. 2, Preamble, Regulation (EU) No 1026/2012 of the European Parliament and of the Council of 25 October 2012 on certain measures for the purpose of the conservation of fish stocks in relation to countries allowing non-sustainable fishing: http://faolex.fao.org/docs/pdf/eur117342.pdf. This would allow a countermeasure to be taken by the Union against a responsible 'country' for a breach of its obligations under LOSC or another fishing management agreement. On the other hand, the Preamble of the Commission Implementing Regulation 793/2013 of 20 August 2013 establishing measures in respect of the Faeroe Islands to ensure the conservation of the Atlanto-Scandian herring stock, which is the instrument specifically introducing measures in this particular case pursuant to Regulation 1026/2012, explicitly links the measures to conservation objectives, and explains the steps that have been taken in order for the measures to meet the requirements of the chapeau of GATT Article XX. Paras. 23-28, Preamble, Commission Implementing Regulation (EU) No 793/2013. It also states that the measures 'relate to the conservation of an exhaustible fish stock and aim at the avoidance of over-exploitation of the stock made effective, since the measures aim to maintain the Atlanto-Scandian herring stock within safe biological limits.' Para. 27, Preamble, Commission Implementing Regulation (EU) No 793/2013. Although the purpose of inducing the responsible subject to comply with its obligations to cease the wrongful act might have been present, there is no evidence in the text and context of Commission Implementing Regulation 793/2013 that the specific measures were taken with this intention. Second, pursuant to the provisions of Regulation 1026/2012, such measures have to be proportionate (Article 5(c)). The question arises as to how proportionality is to be gauged: if it has been assessed by reference to the injury suffered, it would provide some evidence that the measures were intended to fulfill the requirement of proportionality of countermeasures. If measured by reference to the measure's purpose of effectively preventing further damage to the sustainability of the herring stock, this would provide evidence that the measure was taken within the ambit of the exceptions under GATT Article XX(g). Regulation 1026/2012 allows for measures to be taken on either of these grounds, and this is evident in relation to the proportionality requirement that it establishes. According to Article 5(c) of Regulation 1026/2012 the measures have to be proportionate 'to the objectives pursued and compatible with the obligations imposed by international agreements to which the Union is a party and any other relevant norms of international law.' This requirement is sufficiently wide to include both the proportionality required under the chapeau of the general exceptions of GATT Article XX and proportionality required under customary international law for lawful countermeasures: proportionality to the injury suffered taking into account the rights in question (ASR Article 51; Gabčvkovo-Nagymaros Project (Hungary/Slovakia), Judgment of 25 September 1997, ICJ Reports 1997, p. 7, para. 85). For the purposes of the measures taken against the Faroe Islands in this case, the Preamble (para. 27) of Commission Implementing Regulation 793/2013, indicates that proportionality was couched in terms of GATT Article $\mathrm{XX}(\mathrm{g})$. 
requirements of the general exceptions under GATT and supplementarily the countermeasures' requirements under customary international law. In the latter case, the wrongfulness of the EU's conduct would be precluded should the measures not meet the requirements of the general exceptions under GATT Article XX $(\mathrm{g})$. $^{34}$

Seen through these lenses, the EU's conduct prior to adopting Commission Implementing Regulation (EU) No 793/2013 may be compatible with the obligation to offer to the responsible subject to negotiate and to request the responsible subject to cease the wrongful act, and to notify that countermeasures will be taken (ASR Article 52(1)). ${ }^{35}$ When the Faroe Islands responded that they were unwilling to rectify their unilateral measures, the Commission adopted measures that would be 'effective and proportionate to achieve their conservation objective and should prevent the Faeroe Islands to take advantage of the Union markets, ports and facilities to maintain its unsustainable fishery for herring. ${ }^{36}$ Furthermore, they could also meet the requirements of proportionality (vis-à-vis the injury suffered by the EU when the Faroe Islands violated their obligations under the 2007 Agreement). ${ }^{37}$

Finally, the measures were repealed in 2014, when the Faroe Islands and the EU reached an agreement, ${ }^{38}$ after Denmark (on behalf of the Faroe Islands) initiated proceedings against the Union under the WTO Dispute Settlement Understanding $\left(\right.$ 'DSU') ${ }^{39}$ and LOSC. ${ }^{40}$

Assuming arguendo that this was a countermeasure taken by the EU, the question arises whether the EU was acting as an injured subject or as a subject other than the injured subject, essentially resorting to 'third party countermeasures' in the latter case. As it is explained in section 2.1.3.2 below, there is some doubt as to whether third party countermeasures are permitted under customary international law. The question as to whether the EU responded as an injured subject or as a subject other than the injured subject can only be answered as by interpreting the primary rule; in this case, the obligation allegedly breached by the Faroe Islands concerning TAC. In this respect the problem is about classifying obligations of TAC in the context of fisheries agreements. If the obligations are seen as obligations relating to management of resource exploitation

\footnotetext{
${ }^{34}$ For in-depth analysis of the issue: Azaria (2015), supra note 13, pp. 80-88. These measures could not have been taken under the law of treaties, which would have allowed solely the unilateral suspension of the same agreement's operation (VCLT Article 60(2)(b)), assuming that such a rule would mutatis mutandis apply international agreements other than treaties.

35 Preamble para. 15, Commission Implementing Regulation (EU) No 793/2013.

36 Preamble para. 20, ibid.

${ }^{37}$ The threshold by which proportionality under GATT Article XX and countermeasures under the law of international responsibility is gauged differs. The latter's criterion is the injury suffered taking into account the rights in question. ASR Article 51.

${ }^{38}$ Commission Implementing Regulation (EU) No 896/2014 of 18 August 2014 repealing Implementing Regulation (EU) No 793/2013 establishing measures in respect of the Faroe Islands to ensure the conservation of the Atlanto-Scandian herring stock. See also: Prime Minister welcomes understanding to resolve dispute on EU's economic measures, 12 June 2014: http://www.government.fo/news/news/prime-minister-welcomes-understanding-to-resolve-dispute-oneu-s-economic-measures/.

${ }^{39}$ Request for Consultations by Denmark in Respect of the Faroe Islands, European Union - Measures on Atlanto-Scandian Herring, 4 November 2013 (terminated on 21 August 2014); Understanding on Rules and Procedures Governing the Settlement of Disputes, Annex 2 to the Agreement establishing the World Trade Organization (done in Marrakesh 15 April 1994, entered into force 1 January 1995) 1869 UNTS 401.

${ }^{40}$ Denmark, in respect of the Faroe Islands, initiated arbitration proceedings under Annex VII of LOSC, invoking Articles 287 and 288(1) of LOSC, and Article 1 of Annex VII to LOSC. The dispute concerned the interpretation and application of LOSC Article 63(1) in relation to the shared stock of AtlantoScandian herring: http://www.pca-cpa.org/showpage9190.html?pag_id=1554. For termination of proceedings: http://www.pca-cpa.org/2013-30\%20-20140923\%20\%20Termination $\% 20$ Ordercbbd.pdf?fil_id $=2770$.
} 
prescribing that all have to abstain from unilaterally and at their own rate exploit the resource, then the obligation is better classified as interdependent. The obligation requires everyone to comply with it in order for everyone else to perform; it is based on a 'global synallagma'. ${ }^{41}$ On the other hand, if it is perceived as an obligation concerning the conservation and protection of a natural resource it is better understood as characterized by a rationale that transcends the individual interests of the subjects, which bear that obligation. $^{42}$ This determination is difficult to make, and there is no evidence from the practice of the EU or of the other parties to the Agreement as to what type of standing the EU would have in this situation.

Although Annex II to the 2007 Agreed Record is entitled 'Arrangement on the Long-term Management [...]', it also states that the parties have agreed to implement this arrangement, "which is consistent with the precautionary approach, intended to constrain the harvesting within safe biological limits and designed to provide for sustainable fisheries'. This language could be seen as evidence that the obligations therein are intended to protect a resource in an integral manner, rather than putting emphasis on the individual interests of the parties. As such, the alleged countermeasure would be taken for a breach of an erga omnes partes obligation and the EU's standing in that case would either be that of an subject other than the injured subject (in fact in this situation it is unlikely that there was an injured subject) or as an injured subject to the extent that it could show that it was specially affected (by comparison to the other parties to the arrangement).

This example illustrates the difficulty of identifying whether a measure has been taken in response to a perceived non-compliance, or with a view to protecting environmental values or natural resources concerns especially in the context of obligations that have to do specifically with the management and conservation of natural resources. It is also possible that given the lack of clarity as to whether 'third party countermeasures' are available to subjects other than the injured subject, the EU had an additional reason for being reluctant to suggest that it is taking countermeasures against the Faroe Islands, to which the TFEU does not apply (TFEU Article 355(5)(a)), but they are part of an EU member state.

Furthermore, this dispute has shown that countermeasures may escalate an existing dispute, notwithstanding the fact that this is not their purpose, ${ }^{43}$ and that they come with a risk of auto-determination. Against this background, the importance of third party dispute settlement with a view to resolving disputes that may arise and may involve unilateral reactions is highlighted. In this context, the dispute settlement provisions were not invoked by the EU but against it in fora and for violations of its obligations in the form of the measures taken against the Faroe Islands' conduct.

The following section examines the practice of the EU in resorting to 'third party countermeasures'.

\footnotetext{
${ }^{41}$ For classification of international obligations in this respect: L.-A. Sicilianos, The Classification of Obligations and the Multilateral Dimension of the Relations of International Responsibility, 13 EJIL (2002) 1127-1145.

${ }^{42}$ In the ASR erga omnes partes obligations are those that are 'owed to a group of states and established for the protection of a collective interest of the group of states' (ASR Article 48(1)(a)). See also differences between attempts to classify treaties and the classification of obligations by the ILC: Azaria (2015), supra note 13 , pp. $109-110$.

${ }^{43}$ For the risk of aggravating the dispute and the relationship between countermeasures and dispute settlement, see Azaria (2015), supra note 13, pp. 163-166. The objective of countermeasures is to induce the responsible subject to comply with its obligation to cease the wrongful conduct and to make reparation. See Article 49, Text of the draft articles on the responsibility of states for internationally wrongful acts, Report of the Commission to the General Assembly on the work of its fifty-third session, Yearbook of the International Law Commission, 2001, Vol. II, pp. 26-30.
} 


\subsubsection{EU's Countermeasures against Russia for the latter's Wrongful Conduct in Crimea}

Under international law, when breaches of erga omnes (partes) obligations occur, specially affected subjects are injured, and can resort to countermeasures (ASR Articles 42 and 49; ARIO Articles 43 and 51). The United Nations ('UN') International Law Commission ('ILC') in 2001 and 2011 considered that the practice of 'third party countermeasures' was embryonic. ${ }^{44}$ The ASR and ARIO include 'a saving clause which $[\ldots]$ leaves the resolution of the [question whether there is a customary right of states other than an injured state to resort to countermeasures] to the further development of international law ${ }^{45}$ (ASR Article 54; ARIO Article 57).

However, the question about the availability and lawfulness of 'third party countermeasures' is not new. Literature has resorted to de lege ferenda arguments. ${ }^{46} \mathrm{On}$ the other hand, a number of authors since the adoption of the ASR in 2001 have argued that the practice of 'third party countermeasures' is not scarce, and that the law on state responsibility permits 'third party countermeasures'. ${ }^{47}$ In fact, some authors suggest that state practice before the adoption of ASR was substantial and sufficient for the emergence of a rule of customary international law that allows countermeasures by states and international organisations other than the injured state. ${ }^{48}$

This contribution however does not address the question of the lawfulness of the Union's measures. Rather it illustrates that the practice of the EU has been and continues to be instrumental in shaping the law of implementing international responsibility for breaches of erga omnes obligations.

The most recent example is the EU countermeasures against Russia for the latter's prohibited use of force against Ukraine in 2014. Russia used force against Ukraine and subsequently annexed parts of the territory of Ukraine in breach of international law. ${ }^{49}$ The obligation not to use force is an obligation erga omnes. ${ }^{50}$

\footnotetext{
${ }^{44}$ Text of the draft articles on responsibility of States for internationally wrongful acts with commentaries thereto, Report of the Commission to the General Assembly on the work of its fifty-third session, Yearbook of the International Law Commission, 2001, Vol. II, pp. 31-143 at 137, para. 3.

45 Ibid at 129, para. 8, p. 137, para. 3, p. 139, para. 6-7; Text of the draft articles with commentaries thereto, Report of the International Law Commission, Sixty-third session (26 April-3 June and 4 July-12 August 2011), General Assembly, Official Records, Sixty-sixth session, Supplement No. 10 (A/66/10), pp. 67-170, at 154 , para. 1 to p. 155 , para. 2.

${ }^{46}$ M. Akehurst, Reprisals by Third States, 44 BYIL (1970) 1-18; M. Koskenniemi, Solidarity Measures: State Responsibility as a New International Order?, 72 BYIL (2001) 337-356.

47 Sicilianos argues that there is abundant practice of countermeasures taken by states other than the injured state. L.-A. Sicilianos, in J. Crawford, A. Pellet, and S. Olleson (eds), The Law of International Responsibility (Oxford University Press, 2010), pp. 1146-1148; C.J. Tams, Enforcing Obligations Erga Omnes in International Law (Cambridge University Press, 2005) pp. 90-91, 208-225.

${ }^{48}$ L.A. Sicilianos, in J. Crawford, A. Pellet and S. Olleson (eds), The Law of International Responsibility (Oxford University Press, 2010), pp. 1137-1148 at 1146-1148.

49 J.A. Green, The Annexation of Crimea: Russia, Passportisation and the Protection of National Revisited, 1 Journal on the Use of Force and International Law (2014) 3-10 at 5; T. Christakis, Les conflits de la sécession en Crimée et dans l'est de l'Ukraine et le droit international, 141 Journal du droit international (2014) 733-764 at 750.

${ }^{50}$ Dissenting Opinion of Judge Schwebel, Military and Paramilitary Activities in and against Nicaragua (Nicaragua v. United States of America), Provisional Measures, Order of 10 May 1984, I.C.J. Reports 1984, p. 169 at 198. For the more narrow category of aggression: Barcelona Traction, Light and Power Company, Limited, Second Phase, Judgment of 5 February 1970, ICJ Reports 1970, p. 3 at 32, paras. 33-34.
} 
Starting from March 2014, the $\mathrm{EU}^{51}$ adopted a series of measures against Russia. Initially the measures taken involved the freezing of assets and visa bans. ${ }^{52}$ Later the measures were intensified requiring export restrictions of dual-use goods and equipment, but also restrictions on services, and restrictions on the sale, supply, transfer or export, directly or indirectly, of certain technologies for the oil industry in Russia in the form of a prior authorisation requirement. ${ }^{53}$ In September 2014, the EU prohibited the provision of services for deep-water oil exploration and production, arctic oil exploration and production or shale oil projects. It also prohibited legal/natural persons to directly or indirectly purchase, sell, provide investment services for or assistance in the issuance of, or otherwise deal with transferable securities by a number of Russian energy companies. ${ }^{54}$

These measures constituted prima facie violations of the WTO Agreement (GATT and the General Agreement on Trade in Services ('GATS')) ${ }^{55}$ to which both the EU and Russia are parties. ${ }^{56}$ For instance, export restrictions on technology in the energy sector would arguably be incompatible with the obligation not to quantitatively restrict exports (under GATT Article XI), while prohibiting brokering services may arguably be incompatible with GATS Article II. ${ }^{57}$ If the measures of the EU fall within the ambit of GATT Article XXI(b)(iii) or GATS Article XIV bis respectively, they are not prohibited by the GAT'T or GATS and are lawful.

Although what constitutes 'essential security interests' within the meaning of GATT Article XXI(b)(iii) or GATS Article XIV bis is a 'self-judging' matter, ${ }^{58}$ measures taken under this provision are subject to the jurisdiction of the WTO DSU Panels and Appellate Body. WTO members are at least obliged to furnish good faith evidence that they are protecting their own essential security interests and the necessity of the measures can also be reviewed. ${ }^{59}$ Given that the prohibition of the use of force constitutes a

\footnotetext{
51 Council Decision 2014/145/CFSP of 17 March 2014 concerning restrictive measures in respect of actions undermining or threatening the territorial integrity, sovereignty and independence of Ukraine; Council Decision 2014/512/CFSP of 31 July 2014 concerning restrictive measures in view of Russia's actions destabilising the situation in Ukraine; Council Regulation (EU) No 833/2014 of 31 July 2014 concerning restrictive measures in view of Russia's actions destabilising the situation in Ukraine; Council Regulation (EU) No 960/2014 of 8 September 2014 amending Regulation (EU) No 833/2014 concerning restrictive measures in view of Russia's actions destabilising the situation in Ukraine; Council Regulation (EU) No 1290/2014 of 4 December 2014 amending Regulation (EU) No 833/2014 concerning restrictive measures in view of Russia's actions destabilising the situation in Ukraine, and amending Regulation (EU) No 960/2014 amending Regulation (EU) No 833/2014.

52 Council Decision 2014/145/CFSP of 17 March 2014 concerning restrictive measures in respect of actions undermining or threatening the territorial integrity, sovereignty and independence of Ukraine.

${ }^{53}$ Council Decision 2014/512/CFSP of 31 July 2014 concerning restrictive measures in view of Russia's actions destabilising the situation in Ukraine.

${ }^{54}$ Article 5, Council Regulation (EU) No 960/2014 of 8 September 2014 amending Regulation (EU) No $833 / 2014$ concerning restrictive measures in view of Russia's actions destabilising the situation in Ukraine.

55 General Agreement on Trade in Services, Annex IB to the Agreement establishing the World Trade Organization (done 15 April 1994, entered into force 1 January 1995) 1869 UNTS 185.

${ }^{56}$ Russia acceded to the WTO Agreement on 22 August 2012. WTO Ministerial Council Decision of 16 December 2011 (with Annex on the Accession Protocol of the Russian Federation), WT/MIN(11)/24WT/L/839, 17 December 2011.

${ }^{57}$ Article 5, Council Regulation (EU) No 833/2014 of 31 July 2014 concerning restrictive measures in view of Russia's actions destabilising the situation in Ukraine.

${ }^{58}$ No WTO case law as yet exists on security exceptions. Indicative literature on GATT Article XXI: D. Akande and S. Williams, International Adjudication on National Security Issues: What Role for the WTO?, 43 VJIL (2002-2003) 365-404; H.L. Schloemann and S. Ohlhoff, 'Constitutionalization' and Dispute Settlement in the WTO: National Security as an Issue of Competence, 93 AJIL (1999) 424-451; M.J. Hahn, Vital Interests and the law of GATT: An Analysis of GATT's Security Exception, 12 MJIL (19901991) 558-620.

${ }^{59}$ D. Akande and S. Williams, International Adjudication on National Security Issues: What Role for the WTO, 43 VJIL (2002-2003) 365-404 at 389-390.
} 
collective obligation owed to everyone (erga omnes), the EU, as a subject other than the injured state, primarily adopts these measures for the protection of the common interest of the international community. It could thus be argued that the measures of the EU (and the US) are not taken for the protection of 'its essential security interests' and the measures go beyond the threshold of GATT Article XXI(b)(iii) and GATS Article XIV bis. On the other hand, the fact that under the law of international responsibility such measure would be taken on the basis of standing for the breach of an erga omnes obligation, is separate and different from the threshold required within the meaning of GATT Article XXI and GATS Article XIV bis. While state responsibility is formed of secondary rules, GATT Article XXI and GATS Article XIV bis are part of the primary rules. ${ }^{60}$ Given that these are two different issues, the threshold of GATT Article XXI and GATS Article XIV bis cannot be replaced by the requirements under the law of international responsibility. In other words, the fact that under the law of international responsibility third party countermeasures by the EU would have been taken to protect an interest beyond the EU's individual interests, does not mean that the same interest would not fall within the scope and content of the term 'its essential security interests' within GATT Article XXI and GATS Article XIV bis. If this is the case, the measures would not be unlawful under GATT or GATS to the extent that they were permitted under the security exceptions. As a result, they would constitute retorsion in response to an internationally wrongful act.

If the measures of the EU against Russia cannot be justified under the security exceptions in the WTO covered Agreements (such as, GATT Article XXI(b)(iii)), their wrongfulness would be precluded as 'third party countermeasures' under customary international law. If this is so, there is no evidence in the practice of states - members and non-members of the EU - that the measures of the EU are unlawful. In fact, the United States took similar measures against Russia for similar reasons. ${ }^{61}$ This may suggest a tacit acknowledgment that third party countermeasures are permitted.

\subsubsection{Other Examples of EU Practice}

\footnotetext{
${ }^{60}$ These issue brings to the fore the question as to the relationship between security exceptions in GATT and GATS and countermeasures, as circumstances precluding wrongfulness, under the law of international responsibility. For instance, the wording '[n]othing in [GATT] shall be construed to prevent any contracting party from taking any action [...] for the protection of its essential security interests taken in time of [...] other emergency in international relations' in GATT Article XXI(b)(iii) overlaps with a situation addressed by countermeasures under the law of international responsibility. Dissenting opinion of Judge Sir Robert Jennings, Military and Paramilitary Activities in and against Nicaragua, Merits, Judgment of 27 June 1986, ICJ Reports 1986, p. 528 at 541. However, there is no evidence that the WTO Agreement and its annexes derogate (as lex specialis) from circumstances precluding wrongfulness in general, and from countermeasures in particular. The wording in this provision suggests that it delineates the obligations under the GATT. No GATT or WTO case law, nor practice of WTO members or supplementary means of interpretation of the GATT suggest that GATT Article XXI deviates from circumstances precluding wrongfulness under customary international law. See detailed analysis of GATT and WTO case law, as well as practice of WTO members concerning this issue in Azaria (2015), supra note 13, pp. 80-88. In fact, while detailed rules concerning unilateral 'countermeasures' were introduced in the DSU as a means of implementing responsibility for breaches of WTO obligations (besides for non-violation claims), there is no provision about circumstances precluding wrongfulness, despite the fact that the issue of the relationship between countermeasures under custom and the GATT had arisen in the pre-WTO era. Ibid, pp. $86-87$.

${ }^{61}$ US measures: Executive Order 13660_Blocking Property of Certain Persons Contributing to the Situation in Ukraine, 6 March 2014: http://www.gpo.gov/fdsys/pkg/FR-2014-03-10/pdf/201405323.pdf; and subsequently on 12 September 2014: http://www.treasury.gov/press-center/pressreleases/Pages/j12629.aspx.
} 
Other examples of countermeasures taken by EU member states for breaches of erga omnes obligations were the freezing of funds and assets of the Federal Republic of Yugoslavia and the Serbian Government in 1998 contrary to international obligations. ${ }^{62}$ Moreover, a flight ban was imposed, which at least for France and the UK was contrary to their international obligations under bilateral aviation treaties with Yugoslavia. ${ }^{63}$

In recent years, EU responses to breaches of erga omnes obligations, such as the prohibition of aggression, or grave human rights violations, take a more targeted form: they involve asset freezes and travel bans that target specific individuals involved in such breaches. ${ }^{64}$ Examples include the measures imposed on the members of the Zimbabwean Government (2005), ${ }^{65}$ and in relation to Crimea (2014). ${ }^{66}$ In relation to this type of responses the question arises as to their compliance with two conditions of lawfulness of countermeasures under customary international law. First, countermeasures have to be targeted against the responsible state (ASR Article 49(1)). It could be argued that such measures are not targeted against the responsible state, but rather against individuals. However, this type of conduct can be seen as targeted against the responsible state, in the sense that it targets nationals of the target state. Its form may directly affect individuals, but they are targeted owing to their link with the responsible state and in response to the wrongful act of the state. Second, countermeasures shall not affect fundamental human rights obligations (ASR Article 50(1)(b)). ${ }^{67}$ Usually such countermeasures affect individuals that are located outside the territory of the EU, and a number of questions will arise about whether the EU (as opposed to member states) is bound by human rights obligations under customary international law; which human rights obligations cannot be affected pursuant to customary international law; whether any such human rights obligations apply or whether there is no exercise of 'jurisdiction' over the individuals in question, given that they are located outside the territory of EU member states where the founding treaties of the EU apply. ${ }^{68}$

${ }^{62}$ Common Position of 7 May 1998 defined by the Council on the basis of Article J.2 of the Treaty on European Union concerning the freezing of funds held abroad by the Federal Republic of Yugoslavia (FRY) and Serbian Governments (98/326/CFSP), OJ L 143/1.

${ }^{63}$ For details see C.J. Tams, Enforcing Obligations Erga Omnes in International Law (Cambridge University Press, 2005) p. 223.

${ }^{64}$ Owing to the limitation in the extraterritorial application of human rights obligations, such as the right to property (assuming that it is a fundamental human right within the meaning of the customary rule on countermeasures; in relation to this issue, see Azaria (2015), supra note 13, pp. 234-236), it may be difficult to establish that such countermeasures affect the fundamental human rights obligations of the EU (under customary international law, as the EU is not party to the ECHR or other human rights treaties that protect such a right). For extraterritorial application of human rights obligations, M. Milanovic, Extraterritorial Application of Human Rights Treaties: Law, Principles, and Policy (Oxford University Press, 2011).

${ }^{65}$ Council Common Position of 18 February 2002 concerning restrictive measures against Zimbabwe (2002/145/CFSP), OJ L 50/1.

${ }^{66}$ Article 2, Council Decision 2014/145/CFSP of 17 March 2014 concerning restrictive measures in respect of actions undermining or threatening the territorial integrity, sovereignty and independence of Ukraine.

${ }^{67}$ For specific discussion in relation to the requirement that countermeasures shall not to affect human rights obligations: Azaria (2015), supra note 13, pp. 232-246.

${ }^{68}$ If the countermeasure involves a restriction of assets within EU member state jurisdiction, such a human right may be affected, and the question then becomes one about whether the right to property is one of the rights not to be affected by countermeasures under the rules of customary international law). See problems surrounding the interpretation of the term 'fundamental human rights' in ASR Article 50(1)(b): Azaria (2015), supra note 13, pp. 234-236). Travel bans could also in certain circumstances violate the right to private life of individuals located outside the territory of the subject taking the countermeasure. See Nada $v$. Switzerland [GC], Judgment (Merits and Just Satisfaction), No. 10593/08, 12 September 2012. 


\subsubsection{Interim Conclusion}

The analysis of a number of measures taken by the EU (or its predecessors) or by member states in the context of the EU framework provides evidence of practice involving suspension of compliance with (trade/economic law) obligations owed to third states who violated erga omnes (partes) obligations. This practice has contributed to a trend towards the concretisation of a rule of customary international law concerning the lawfulness of 'third party countermeasures'.

Having examined the EU practice of countermeasures against third subjects, the following section examines the practice of third state countermeasures against the EU, as a means of invoking the responsibility of the EU.

\subsection{The EU as the Subject of Countermeasures}

The EU can be and has been subject to countermeasures by third states. ${ }^{70}$ There is no abundant practice in this respect, but this is not specific to the EU. In 2011, the ILC noted the lack of practice of countermeasures against IOs in general - whether in response to breaches of bilateral obligations or collective obligations. ${ }^{71}$

On 6 August 2014, Russia adopted a ban on agricultural products from the EU, the US, Canada, Australia and Norway, as a result of the implementation of economic responses against Russia in the context of the situation in Ukraine. On 7 August 2014, the Russian government adopted a list of products to be banned for a period of one year. ${ }^{72}$ The list, which was modified on 20 August 2014, covered specific products over several sectors: fruit and vegetables, dairy products and meat. ${ }^{73} 73 \%$ of imports that were banned originated in the EU.

${ }^{69}$ International organisations have international legal personality, but special/limited competence. As a result, it can be argued that although they can participate in the formation of custom independently from states (including their member states) the limited scope of their competences should be taken into account when examining their practice as an element for the formation of rules of customary international law. T. Treves, Customary International Law, Max Planck Encyclopedia of Public International Law (2006), p. 171. See also about the distinction between the conduct of the organisation and that of the member states: $\mathrm{J}$. Klabbers, International Organizations in the Formation of Customary International Law, in E. Canizzaro and P. Palchetti (eds), Customary International Law on the Use of Force (Martinus Nijhoff Publishers, 2005) pp. 183. The work of the International Law Commission on the Formation and Evidence of Custom is ongoing and takes into account this issue. However, it is not clear what the position of the Commission will be as the Commentary to the Text of the Draft Conclusions Provisionally adopted by the Drafting Committee, 14 July 2015, A/CN.4/L.869 has not as yet been submitted for consideration by the Commission in Plenary. The current draft of the conclusions however may be seen as allowing for the argument that in areas where international organisations have competence their practice may count as relevant for the formation of customary international law. See Draft Conclusion 4(2), Text of the Draft Conclusions Provisionally adopted by the Drafting Committee, 14 July 2015, A/CN.4/L.869; Special Rapporteur Michael Wood, Third Report on Identification of Customary International Law, 27 March 2015, A/CN.4/682, pp. 46-54.

${ }^{70} \mathrm{It}$ has not been possible to identify evidence of countermeasures by other IOs against the EU.

${ }^{71}$ Text of the draft articles with commentaries thereto, Report of the International Law Commission, Sixty-third session (26 April-3 June and 4 July-12 August 2011), General Assembly, Official Records, Sixty-sixth session, Supplement No. 10 (A/66/10), pp. 67-170, at 148, para. 4.

${ }^{72}$ Resolution of the Government of the Russian Federation No. 778 of 7 August 2014 as amended by Resolution No. 830 of 20 August 2014: http://ec.europa.eu/agriculture/russian-import-ban/pdf/list-ofbanned-products-20-08-2014_en.pdf.

${ }^{73}$ ПОСТАНОВЛЕНИЕ от 20 августа 2014 г. N 830, О внесении изменений в постановление Правительства Россииской Федерации от $7 \quad$ августа 2014 г. No 778 : http://government.ru/media/files/41d4fd237c91ea4213b0.pdf. Informal translation: Resolution of the Government of the Russian Federation No. 778 of 7 August 2014 as amended by Resolution No. 830 of 
These measures involved the non-performance of the obligations of Russia under the GATT. Russia allegedly responded to what it considered as unlawful conduct by the EU in the form of breaching the GATT/GATS (taken in response to Russia's unlawful conduct against Ukraine). ${ }^{74}$ The question arises as to the lawfulness of such countermeasures by Russia against the EU.

Countermeasures are based on an 'auto-determination' of whether an internationally wrongful act has occurred against which the countermeasure is taken. ${ }^{75}$ As such they inherently involve a risk: if the retaliating subject makes a mistaken determination, it will itself commit and internationally wrongful act and the wrongfulness of that act will not precluded.

In this particular instance, Russia's measures are not lawful countermeasures. Even assuming arguendo that the EU measures were wrongful ${ }^{76}$ and that their wrongfulness was not precluded, ${ }^{77}$ the allegedly wrongful measures by Russia were in breach of WTO obligations in response to alleged breaches of the WTO Agreement. Under the WTO Agreement, WTO Russia was obliged not to resort to any unilateral measures outside the WTO in response to alleged violations of the WTO Agreement by other WTO members. Rather it was obliged to have recourse only to the WTO DSU. ${ }^{78}$

For the reasons analysed above, Russia's measures against the EU in breach of the GATT would not qualify as lawful countermeasures under customary international law. However, they furnish an example where third states have unilaterally invoked the alleged responsibility of the EU by resorting to unilateral self-help.

\subsection{Interim Conclusion}

This section discussed the practice of the EU or of states against the EU involving recourse to countermeasures as an indication of developing standing to bring a claim under general international law for breaches of international obligations and how these have played out in the context of the disputes they were brought into. It also showed that countermeasures are inextricably connected to dispute settlement, because most disputes that end up in judicial (or quasi-judicial) fora involve questions of responsibility; because countermeasures may prompt the responsible state to get involved in the settlement of the dispute (or comply with its obligation to participate in dispute settlement where such obligation exist); and because countermeasures have also the

20 August 2014: http://ec.europa.eu/agriculture/russian-import-ban/pdf/list-of-banned-products-20-082014_en.pdf.

${ }^{74}$ See section 2.1.3.2 above.

75 Separate Opinion of Judge Simma, Application of the Interim Accord of 13 September 1995 (the former Yugoslav Republic of Macedonia v. Greece), ICJ Reports 2011, p. 699, para. 10.

${ }^{76}$ See analysis in section 2.1.3.2 above.

${ }^{77}$ Even assuming that the EU measures did not meet the thresholds required by the security exceptions in GATT Article XXI(b)(iii) and GATS Article XIV bis, those measures were lawful (their wrongfulness was precluded) as 'third party countermeasures' against Russia's prior wrongful act of use of force and annexation in Ukraine. It is possible that Russia would be claiming that customary international law does not permit 'third party countermeasures' and thus the wrongfulness of these EU measures is not precluded.

78 Panel Report, United States-Import Measures on Certain Products from the European Communities, WT/DS165/R and Add.1, adopted 10 January 2001, as modified by the Appellate Body Report,WT/DS165/AB/R, para. 6.123 and paras. 6.134-6.135; Panel Report, European CommunitiesMeasures Affecting Trade in Commercial Vessels, WT/DS301/R, adopted 20 June 2005, paras. 7.196-7.197; Azaria (2015) supra note 13, pp. 166-172; P.C. Mavroidis, Remedies in the WTO Legal System: Between a Rock and a Hard Place,11 EJIL (2000) 763-813; B. Simma and D. Pulkowski, Of Planets and the Universe: Self-Contained Regimes in International Law, 17 EJIL (2006) 483-529 at 523; J. Gomula, Responsibility and the World Trade Organization, in J. Crawford, A. Pellet, and S. Olleson (eds.), The Law of International Responsibility (Oxford University Press, 2010), pp. 791-801 at 799. 
effect of aggravating disputes and the inherent risk of auto-determination that may lead to wrongful conduct by the subject resorting to them.

The following section will examine the practice of the EU in developing rules of standing and jurisdiction within the context of treaty established judicial or quasi-judicial means of dispute resolution.

\section{Judicial Means of Settlement: Jurisdiction and Standing}

While standing is a matter of admissibility, being an objection against the claim brought by the claimant and challenges whether the claimant has a legal interest to bring the claim, jurisdiction is about the competence of the court to deal with a particular dispute. $^{79}$

The EU has negotiated and become party to treaties that include jurisdiction clauses, which confer power to judicial bodies to deal with disputes between an international organisation and states, or to apply and interpret treaties between states and international organisations. This practice has significantly contributed to the expansion of jurisdiction of (ad hoc) judicial and (permanent) quasi-judicial bodies, which traditionally has been restricted to disputes between or claims against states. ${ }^{80}$ Additionally, the treaty practice of the EU has expanded standing to individuals to bring claims against (not only states but also) international organisations.

The following analysis shows the development of jurisdiction and standing in judicial and quasi-judicial bodies, which have the power to entertain claims by and/or against the EU. The analysis begins with the discussion of judicial means of settlement between states and international organisations under the WTO Agreement and the ECT. Then the bodies, which have the power to entertain claims by individuals against the EU, will be examined; more specifically, arbitral tribunals under the ECT and the Aarhus Convention Compliance Committee. This latter analysis indicates the expansion of standing of individuals in international law by bringing claims against international organisations.

\subsection{Judicial Means of Settlement between the EU and States}

\subsubsection{The World Trade Organization}

\subsubsection{1 'Jurisdiction'}

Given that the machinery for the implementation of international responsibility of IOs or the implementation of responsibility of states by IOs through judicial means is limited in international law, the fact that the EU is a particularly active complainant in the WTO DSU procedures is the exception rather than the rule. As at 21 February 2016, the EU (formerly the EC) has been the claimant in 96 disputes brought under GATT and the WTO/DSU. ${ }^{81}$ This practice is coupled with the lack of practice on behalf of EU member states individually bringing claims against other WTO members. ${ }^{82}$ From the

\footnotetext{
${ }^{79}$ On distinction between jurisdiction and admissibility: supra note 7.

80 See, for instance, ICJ Statute and ICSID Convention respectively.

81 The US was complainant in 107 cases:

http://www.wto.org/english/tratop_e/dispu_e/find_dispu_cases_e.htm\#results.

82 The only available cases are those that claims were brought before the accession of the member state to the EC (now EU). For instance, Request for Consultation by Czech Republic, Hungary - Safeguard Measure on Imports of Steel Products from the Czech Republic, 21 January 1999; Request for Consultation by Hungary, Slovak Republic - Measure Affecting Import Duty on Wheat from Hungary, 19 September 1998, DS143; Request for Consultation by Hungary, Czech Republic - Measure Affecting Import Duty on Wheat from Hungary, DS148;
} 
point of view of standing under the WTO DSU, there is nothing that prevents such eventuality - albeit an individual complaint by a EU member state against another W'TO member would be prohibited under EU law owing to the exclusive competence of the $\mathrm{EU}$ in relation to the common commercial policy.

Similarly, the fact that in the exclusive mandatory dispute settlement framework of the GATT and later the DSU states have regularly brought complaints against the EU (formerly the European Community) for a breach of the 1947 GATT and later the WTO Agreement is unprecedented comparing to claims brought against the EU under other procedures and against other international organisations more generally. As of 21 February 2016, the EU has been the respondent in 80 disputes. $^{83}$

\subsubsection{Standing}

In the context of these disputes the EU - as claimant and as respondent - has contributed to the shaping of the (special) rules of standing under the WTO Agreement (as well as the special rules of enforcement under the DSU). Standing is determined by reference to the nature of international obligations: the question asked in this respect is to whom is the international obligation (that is allegedly breached) owed to.

The nature of WTO obligations has been considered by the Panel in European Communities_-Regime for the Importation, Sale and Distribution of Bananas ('EC-Bananas') and by an Arbitrator in United States-Tax Treatment for 'Foreign Sales Corporations' (Recourse to Arbitration under DSU Article 22.6) ('US-FSC'). The former case dealt with standing as such, while in the latter case the Arbitrator was not examining the issue of standing but the quantitative amount of the countermeasure agreed between the parties to the dispute. ${ }^{84}$ The EU was respondent in the former, and complainant in the latter. ${ }^{85}$

In its long-debated Report in EC-Bananas, the Panel found:

'The United States does produce bananas [...]. Moreover, even if the United States did not have even a potential export interest, its internal market for bananas could be affected by the EC regime and that regime's effect on world supplies and prices. Indeed, with the increased interdependence of the global economy, which means that actions taken in one country are likely to have significant effects on trade and foreign direct investment flows in others, Members have a greater stake in enforcing WTO rules than in the past since any deviation from the negotiated balance of rights and obligations is more likely than ever to affect them, directly or indirectly. Since the United States is likely to be affected by the EC regime, it would have an interest in a determination of whether the EC regime is inconsistent with the requirements of WTO rules. [A] Member's potential interest in trade in goods or services and its interest in a determination of rights and obligations under the WTO Agreement are each sufficient to establish a right to

Request for Consultation by Hungary, Romania - Import Probibition on Wheat and Wheat Flour, 18 October 2001, DS240; Request for Consultation by Hungary, Croatia - Measures Affecting Imports of Live Animals and Meat Products, 9 July 2003, DS297; AB Report, Thailand - Anti-Dumping Duties on Angles, Shapes and Sections of Iron or Non-Alloy Steel and H Beams from Poland, WT/DS122/AB/R, 12 March 2001; Request for Consultations by Poland, Slovak Republic - Safeguard Measure on Imports of Sugar, 11 July 2001, DS235; Request for Consultations by Poland, Czech Republic — Additional Duty on Imports of Pig-Meat from Poland, 16 April 2003, DS289.

83 For the sake of comparison, the US is respondent in 123: http://www.wto.org/english/tratop_e/dispu_e/find_dispu_cases_e.htm\#results.

${ }^{84}$ Decision of the Arbitrator, United States-Tax Treatment for Foreign Sales Corporations'-recourse to Arbitration by the United States under Article 22.6 of the DSU and Article 4.11 of the SCM Agreement, WT/DS108/ARB, circulated 30 August 2002, para. 6.1.

85 This analysis draws heavily on Azaria (2015), supra note 13, pp. 126-130. 
pursue a WTO dispute settlement proceeding. Moreover, we note that this result is consistent with decisions of international tribunals. ${ }^{86}$

The Panel did not uphold expressly that the GAT'T obligations are bilateralisable, erga omnes partes, or interdependent. ${ }^{87}$ Its reasoning was based on the factual interconnectedness of international markets ('interdependence of global economy') and the risk of economic impact, including in the form of supplies and prices, faced by any other WTO member in cases where violations of GATT occur. In support of its findings, the Panel cited the Judgment of the Permanent Court of International Justice ('PCIJ') S.S. Wimbledon, ${ }^{88}$ as well as the provisionally adopted ILC Draft Articles on State Responsibility (1996), particularly Article 40(e) and (f), which encompass bilateral, interdependent, erga omnes (Article 40(e)) and erga omnes partes obligations (Article 40(f)). By including community interest obligations and without distinguishing among these bases, the Panel opened up the debate about whether GATT obligations are erga omnes partes. However, the fact that it cited the page of the S.S. Wimbledon Judgment where the PCIJ addressed the issue of jurisdiction (and by implication standing), rather than the judgment's operative part, offers support to the understanding that rules on standing in the WTO Agreement may be generous and unconnected to the nature of the primary obligations therein.

The US_FSC case was a dispute brought by the US against the EU. The Arbitration proceedings that are examined here concerned the quantum of the countermeasures agreed between the US and the EU (for the former's breach of the Agreement on Subsidies and Countervailing Measures) ${ }^{89}$ The Arbitrator found that the prohibition of the subsidy under the SCM Agreement was an erga omnes obligation. ${ }^{90}$ Presumably the Arbitrator meant erga omnes partes given that the obligations are binding only on WTO members. However, the Arbitrator substantiated his finding by reference to the effects of the measure in question, rather than the obligations' nature and the treaty's object and purpose: 'once such a measure is in operation, its real world effects cannot be separated from the inherent uncertainty that is created by the very existence of such an export subsidy. ${ }^{91}$

While different opinions have been expressed in literature as to the nature of obligations under the WTO Agreement, ${ }^{92}$ the reasoning in EC-Bananas is based on the factual interconnectedness of international markets (interdependence of global economy') and the risk of economic impact, including in the form of supplies and prices, faced by any other WTO member in cases where violations of GATT occur. It implies that a wide pool of WTO members have standing without necessarily upholding that the obligations are collective. Nor does the reasoning of the Arbitrator in US-FCS suggest a

86 Panel Reports, European Communities_Regime for the Importation, Sale and Distribution of Bananas, WT/DS27/R/USA, adopted 25 September 1997, as modified by Appellate Body Report, para. 7.50.

${ }^{87}$ The relevant passage concerning standing is in: Panel Report, European Communities-Regime for the Importation, Sale and Distribution of Bananas, WT/DS27/R/USA, adopted 25 September 1997, as modified by Appellate Body Report, para. 7.50.

88 S.S. Wimbledon, Judgment of 17 August 1923, [1923] PCIJ Ser A, No. 1, p. 11.

${ }^{89}$ Annex 1A on Multilateral Agreements on Trade in Goods to the WTO Agreement, Agreement on Subsidies and Countervailing Measures, 1869 UNTS 14.

${ }^{90}$ Decision of the Arbitrator, United States-Tax Treatment for Foreign Sales Corporations' - recourse to Arbitration by the United States under Article 22.6 of the DSU and Article 4.11 of the SCM Agreement, WT/DS108/ARB, circulated 30 August 2002, para. 6.10.

91 Ibid, para. 6.8

${ }^{92}$ J.H.B. Pauwelyn, A Typology of Multilateral Treaty Obligations: Are WTO Obligations Bilateral or Collective in Nature?, 14 EJIL (2003) 907-951; T. Gazzini, The Legal Nature of WTO Obligations and the Consequences of their Violation, 17 EJIL (2006) 723-742; C. Carmody, WTO Obligations as Collective, 17 EJIL (2006) 419-443. 
different understanding of the obligations under the SCM Agreement, despite the reference to obligations erga omnes. It is thus better to understand that special rules on standing under the WTO Agreement, as developed by the WTO case law, are generous (but unconnected to the nature of the primary obligations under the WTO Agreement) allowing any WTO member to bring a claim against another in relation to breaches of the WTO Agreement. ${ }^{93}$

Although these cases have not specifically developed rules on standing to bring claims for breaches of the WTO Agreement owing to the special nature of the EU, they have been paramount for the WTO dispute settlement system and the EU has contributed to this development by influencing the reasoning of the WTO Panel and Arbitrator in the form of its pleadings as claimant and responded respectively.

\subsubsection{The Inter-Contracting Party Arbitration under the Energy Charter Treaty}

The EU is party to the ECT. ${ }^{4}$ Pursuant to Article $27(2)$ of the ECT, Contracting Parties may have recourse to ad hoc arbitration (after a period of negotiations) ${ }^{95}$ that will be conducted in accordance with the UNCITRAL Arbitration Rules (ECT Article 27(3)(f)). This arbitral procedure has not been used by the EU or against the EU. In fact, no ECT Contracting Party has used it as at 31 July 2015. Nevertheless, this arbitration clause adds to the 'widening' of jurisdiction of ad hoc judicial fora which is competent to entertain disputes between an international organisation (the EU) and a state (another ECT Contracting Party).

\subsection{Individuals against the EU}

Individuals cannot per se invoke the responsibility of states or of international organisations for breaches of international obligations, in the absence of some form of state consent. ${ }^{96}$ However, states and international organisations may specifically consent to give such entitlement to individuals by treaty. The instances of claims brought by individuals against international organisations for the latters' violation of international law in an international forum are exceptionally rare. The EU is the only international organisation that has subjected itself to the 'jurisdiction' of international judicial or quasijudicial fora in which complaints concerning its compliance with international law can be brought by individuals.

The accession of the EU to the Convention for the Protection of Human Rights and Fundamental Freedoms ('ECHR') ${ }^{97}$ would allow individuals to invoke the responsibility of the EU for breaches of the ECHR before the European Court of Human Rights ('ECtHR'). ${ }^{98}$ Nevertheless, the area that has prompted such unprecedented development

93 J. Crawford, Multilateral Rights and Obligations in International Law, 319 RCADI (2006) 325-482 at 451. This paper does not examine complaints for conduct that does not involve the breach of the WTO Agreement, as it focuses on international responsibility.

${ }^{94}$ EU member states are also parties to the ECT. On 30 December 2014, Italy notified its withdrawal from the ECT to the Depository of the ECT (the Government of Portugal) pursuant to ECT Article 47. Pursuant to ECT Article 47(2) the withdrawal shall take effect upon the expiry of one year after the date of the receipt of the notification by the Depository, or on such later date as maybe specified in the notification of withdrawal. Assuming that Italy's notification does not determination a precise date on which the withdrawal takes effect, Italy's withdrawal took effect on 30 December 2015.

${ }^{5}$ ECT Article 27(1).

${ }^{96}$ R. Higgins, Problems \& Process, International Law and How We Use It (Oxford University Press, 1994), at 54.

${ }_{97}$ Convention for the Protection of Human Rights and Fundamental Freedoms (signed at Rome 4 November 1950, entered into force on 3 September 1953) 213 UNTS 221.

${ }^{98}$ Draft revised agreement on the accession of the European Union to the Convention for the Protection of Human Rights and Fundamental Freedoms: 
is not international human rights law. Rather standing to bring such proceedings against the EU has been developed in the area of investment protection and participatory rights for the protection of the environment outside human rights treaties. ${ }^{99}$

More specifically, the ECT entitles investors (within the meaning of that treaty) to bring claims against ECT Contracting Parties, including the EU, for a breach of the ECT obligations concerning the protection of investors in the framework of arbitration procedures. In addition, the Convention on Access to Information, Public Participation in DecisionMaking and Access to Justice in Environmental Matters ('Aarhus Convention') gives standing to individuals to bring complaints against the treaty parties, including the EU, concerning non-performance of treaty obligations, and provides 'jurisdiction' to the Aarhus Compliance Committee to deal with complaints brought by individuals against treaty parties. $^{100}$

\subsubsection{The ECT Investor-EU Arbitration Procedure}

Under ECT Article 26, investors nationals of an ECT Contracting Party may bring claims against another ECT Contracting Party for a violation of Part III of the ECT concerning the protection of investment. ${ }^{101}$ Investors may initiate disputes under ICSID, UNCITRAL Arbitration Rules or before the Arbitration Institute of the Stockholm Chamber of Commerce (ECT Article 26(4)).

According to Article 26(3)(b)(ii) all Contracting Parties listed in Annex ID are obliged to provide, for transparency reasons, a written statement of their policies, practices and conditions, which do not allow an investor to resubmit the same dispute to international arbitration at a later stage in accordance with Article 26(3)(b)(i). The EU made such a statement, but its statement does not exclude the possibility of an investor of another ECT Contracting Party from bringing a claim under international arbitration against the EU. ${ }^{102}$ However, although the ECT does not prohibit a EU national or a company organised according to the laws of a European member state to bring a claim

http://www.coe.int/t/dghl/standardsetting/hrpolicy/Accession/Meeting_reports/47_1(2013)008rev2_E N.pdf. See, Opinion 2/13 of the Court (Full Court) of 18 December 2014. This issue falls outside the scope of this paper.

${ }^{99}$ For the difference between international human rights law and treaties specifically dealing with participatory rights in environmental matters: P. Birnie, A. Boyle and C. Redgwell, International Law and the Environment (Oxford University Press, 3rd ed., 2009), pp. 296.

${ }^{100}$ Convention on Access to Information, Public Participation in Decision-Making and Access to Justice in Environmental Matters (done in Aarhus 25 June 1998, entered into force 30 October 2001) 2161 UNTS 447.

101 Whether an investor national of a EU member state can bring a claim against another EU member state is beyond the scope of this paper. There is no provision in the ECT that prohibits this outcome. A number of pending investment-arbitration procedures involve this particular situation and will address this question: RENERGY S.à.r.l. v. Spain, ICSID Case No. ABR/14/18; RWE Innogy GmbH and RWE Innogy Aersa S.A.U. v. Spain, ICSID Case No. ABR/14/34; Stadtwerke München GmbH, RWE Innogy GmbH et al. v. Spain, ICSID Case No. ABR/15/1. Beyond but similarly to the ECT, the argument that intra-EU bilateral investment treaties have been terminated upon accession to the EU and that are inapplicable owing to the primacy of EU law has been rejected by arbitral tribunals: Achmea B.V. (formerly known as "Eureko B.V.") $v$. The Slovak Republic, Award on Jurisdiction, Arbitrability and Suspension, 26 October 2010, paras. 231-277.

102 The Statement explains that 'The European Communities and their Member States have both concluded the Energy Charter Treaty and are thus internationally responsible for the fulfilment of the obligations contained therein, in accordance with their respective competences. The [Union] and the Member States will, if necessary, determine among them who is the respondent party to arbitration proceedings initiated by an Investor of another Contracting Party. In such case, upon the request of the Investor, the Communities and the Member States concerned will make such determination within a period of 30 days': http://www.encharter.org/fileadmin/user_upload/document/Annex_ID.pdf. 
against the EU, this would not be permitted under the ECT because such investor would not be an 'Investor of another Contracting Party' as required by ECT Article 26(1). ${ }^{103}$

Arbitral proceedings against the EU by an investor have not as yet been brought in practice. However, it remains a possible means of recourse to investors under the ECT, and may arise in the future under the UNCITRAL Arbitration Rules or before the Arbitration Institute of the Stockholm Chamber of Commerce (ECT Article 26(4)), ${ }^{104}$ depending on the choice made by the Claimant. ${ }^{105}$

\subsubsection{The Aarhus Convention Compliance Committee}

The EU is party to the Aarhus Convention, but not all EU member states are party to it. Individuals can thus bring a claim against the EU for its own conduct which however relates to the conduct of an EU member state that is not party to the Aarhus Convention. ${ }^{106}$ Under the Aarhus Convention, a Compliance Committee has been established to which treaty parties, the Secretariat and individuals ('members of the public') may bring complaints concerning the breach of the Aarhus Convention by a treaty party, including the EU. Complaints against the EU alone, a member state alone, or against the Union and a Member State together may be brought and have been brought before the Compliance Committee. ${ }^{107}$

The Compliance Committee does not directly deal with and does not couch its analysis in terms of international responsibility. However, to the extent that it makes determinations as to the compliance of parties' measures with the Aarhus Convention, it is involved in determining whether international responsibility has been engaged. These proceedings, whose form is adversarial (the individual brings the complaint against a party to the Aarhus Convention), offer a forum where standing to invoke the responsibility of the EU has been afforded to individuals, and the forum (which is not judicial, as it can only make non-binding recommendations) has the competence to hear disputes involving an international organisation (the EU) that is party to the Aarhus Convention.

\section{Conclusions}

Given the limited jurisdiction of international courts and tribunals to adjudicate upon claims by and against international organisations, such as the ICJ, diplomatic means of dispute resolution (negotiation, enquiry, mediation, and conciliation) ${ }^{108}$ remain an

103 M. Burgstaller, European Law and Investment Treaties 26 Journal of International Arbitration (2009) 181 at 206-207.

104 The EU is not party to the ICSID Convention.

105 See also Electrabel S.A. (Belgium) v. Republic of Hungary, Decision on Jurisdiction, 30 November 2012, para. 3.21 .

106 See complaint against the EU and findings by the Aarhus Compliance Committee concerning noncompliance of the EU with the Aarhus Convention in relation to renewable projects in Ireland, which is not party to the Aarhus Convention. Aarhus Compliance Committee, Findings and recommendations with regard to communication ACCC/C/2010/54 concerning compliance by the European Union, 29 June 2012.

107 e.g. Aarhus Compliance Committee, Report concerning compliance by the European Union, ECE/MP.PP/2008/5/Add.10, 2 May 2008; Findings and recommendations with regard to communication ACCC/C/2012/68 concerning compliance by the European Union and the United Kingdom of Great Britain and Northern Ireland, Adopted by the Compliance Committee on 24 September 2013, ECE/MP .PP/C.1/2014/5, 13 January 2014.

108 Article 33(1), UN Charter. J.G. Collier and A.V. Lowe, The Settlement of Disputes in International Law: Institutions and Procedures (Oxford University Press, 1999), pp. 20-30; J.G. Merrills, The Means of Dispute Settlement, in M.D. Evans (ed.), International Law (Oxford University Press, 3rd ed., 2010), pp. 559-585; 
important option for the settlement of disputes between the EU and other subjects of international law. ${ }^{109}$ Diplomatic means are by default available, and may at times assist in the conclusion of a special agreement for arbitration between the parties to the dispute.

Nevertheless, the EU has been instrumental in shaping the law on standing and jurisdiction in the context of international dispute settlement in a variety of areas. First, countermeasures are a means of invoking responsibility and as a result recourse to them provides evidence as to the content of rules of standing under general international law. The EU has contributed to the elaboration of practice concerning countermeasures in response to breaches of international obligations, including practice concerning third party countermeasures for violations of erga omnes (partes) obligations, such as the prohibition of the use of force and grave violations of human rights. In addition, from the point of view of dispute settlement, countermeasures may be instrumental for inducing the responsible subject to settle a dispute, although they may also aggravate the dispute. The EU practice illustrates these effects of countermeasures to which itself has resorted to.

Second, the EU has contributed to significant treaty practice that confers jurisdiction to international judicial and quasi-judicial fora to entertain claims concerning the responsibility (or non-compliance) of states and international organisations either brought by states or brought by IOs against states. It has also provided with significant experience been a pioneer in conferring standing to individuals to bring claims against IOs for a violation of the latters' international obligations. Surprisingly the area where this practice is rooted is not human rights, but rather investment protection and participatory rights in relation to environmental concerns.

J.G. Merrills, International Dispute Settlement (5th ed., 2011), pp. 1-82; For the advantages of judicial means in terms of (legal and actual) finality over non-judicial means, such as conciliation: H. Lauterpacht, The Function of Law in the International Community, Reprinted (Oxford University Press, 2012), p. 276.

109 Although this issue has not been the focus of this study, the EU has also played a significant role in the context of the settlement of disputes between other subjects of international law, for instance by mediating disputes between third states: e.g. Council of the European Union, Concept on Strengthening EU Mediation and Dialogue Capacities, 10 November 2009: http://eeas.europa.eu/cfsp/conflict_prevention/docs/concept_strengthening_eu_med_en.pdf 